\title{
ADDENDUM
}

doi:10.1038/nature05188

\section{Sustainability of three apple production systems}

John P. Reganold, Jerry D. Glover, Preston K. Andrews

$\&$ Herbert R. Hinman

\section{Nature 410, 926-930 (2001)}

We wish to clarify links between us and Stemilt Growers Inc., a commercial fruit company in Washington State, USA, regarding this Letter. The study site was part of a commercial orchard in the Yakima Valley, Washington. At the start of the study in 1994, Stemilt Growers Inc. did not own any part of the farm. Farmer Andy Dolph was a field consultant for Stemilt Growers, but the company had no involvement with the design, location or assessment of the experiment. In 1996 Stemilt Growers bought part of the farm, but they took over management of the farm only at the end of the 2001 growing season, whereas our Nature paper covered previous growing seasons. Stemilt Growers created the Responsible Choice environmental-impact rating system used in our study but had nothing to do with our decision to use this rating system, did not suggest that we should examine environmental impact, and were not involved in our evaluation of the farming systems. A more detailed version of this statement is available online as Supplementary Information to this Addendum.

Supplementary Information is linked to the online version of the paper at www.nature.com/nature. 